Review

\title{
Association Between Interleukin-6 and Head and Neck Squamous Cell Carcinoma: A Systematic Review
}

\author{
Uzdan Uz ${ }^{1}$ (i) $\cdot$ Görkem Eskiizmir² (1) \\ ${ }^{1}$ Department of Otolaryngology-Head and Neck Surgery, Izmir Bozyaka Training and Research Hospital, University of Health Sciences, Izmir; \\ ${ }^{2}$ Department of Otolaryngology-Head and Neck Surgery, Manisa Celal Bayar University, Manisa, Turkey
}

Interleukin-6 (IL-6) is a proinflammatory cytokine which plays an important role in several regulatory mechanisms of cancer. Moreover, experimental and clinical studies have reported that IL-6 targeted therapies might provide significant benefits for cancer treatment. The purpose of this systematic review is to evaluate IL- 6 activity in patients with head and neck squamous cell carcinoma (HNSCC). A systematic review of the association between serum, saliva and tumor IL- 6 and HNSCC was developed on PubMed/Medline in the publication range from January 1995 to January 2019. Our literature analysis demonstrated that overexpression and elevated serum and/or saliva IL-6 concentrations in patients with HNSCC are related to poor survival and oncological outcomes. Although there is a correlation between IL-6 concentrations and tumorigenicity, it is noteworthy that IL-6 targeted therapies are generally performed in vitro and in experimental studies. Therefore, prospective, randomized clinical trials are required that focus on IL-6 targeted therapies for the treatment of HNSCC.

Keywords. Interleukin 6; Survival; Carcinogenesis; Inflammation; Head and Neck Neoplasms

\section{INTRODUCTION}

Head and neck cancer (HNC) is the sixth most common cancer worldwide and accounts for more than 600,000 new cases every year [1,2]. In 1990, the US economic burden of HNC was approximately 1 billion dollars annually [1]. Squamous cell carcinoma, which mainly arises from the mucosa lining the aerodigestive system, is the most common histopathological type of HNC [3]. Despite tremendous advances in the fields of diagnosis and treatment, survival outcomes are still suboptimal with a 5 -year survival rate of less than 50\% [4]. Hence, diagnostic (benign vs. malignant), predictive and prognostic biomarkers for head and neck squamous cell carcinoma (HNSCC) are urgently required in order to attain satisfactory clinical and oncological

\footnotetext{
- Received June 11, 2019

Revised October 4, 2019

Accepted November 13, 2019

- Corresponding author: Uzdan Uz

Department of Otolaryngology-Head and Neck Surgery, Izmir Bozyaka

Training and Research Hospital, Saim Çıkrıçıı Cd. No:59,

35170 Karabağlar İzmir,Turkey

Tel: +90-232-2505050, Fax: +90-232-5815688

E-mail:dr.uzdan@uzdan.net
}

outcomes. To date, a variety of biological materials (serum, saliva, tumor specimens, body fluids, etc.) have been tested as tumor biomarkers for HNSCC [5-12]. Disappointingly, an ideal "biomarker" for HNSCC has not emerged for clinical use yet. Nevertheless, the quest for a well-validated, highly sensitive and specific "biomarker" still continues.

Recently, a variety of clinical and experimental studies have determined the key roles of interleukin-6 (IL-6) in several mechanisms of various cancers such as lymphoma, multiple myeloma, prostate, bladder, breast and colorectal cancers [13-17]. IL-6 is a multifunctional and pleiotropic cytokine which is secreted from monocytes, fibrocytes, keratinocytes, endothelial cells, adipocytes, T- and B-lymphocytes, and cancerous cells. It is one of the major regulators of the immune system and orchestrates several biological events such as inflammation, hematopoiesis, acute phase response, cellular proliferation and differentiation, apoptosis and carcinogenesis. IL-6 signals through two different receptors: IL-6 receptor (IL-6R) and gp130. In human, while all cells are able to excrete the gp130 receptor, IL-6R is unique and exclusively excreted by hepatocytes, neutrophils, monocytes/macrophages and lymphocytes. Both of these receptors are located in the cell membrane and plasma. It is notewor-

Copyright @ 2021 by Korean Society of Otorhinolaryngology-Head and Neck Surgery

This is an open-access article distributed under the terms of the Creative Commons Attribution Non-Commercial License (https://creativecommons.org/licenses/by-nc/4.0)

which permits unrestricted non-commercial use, distribution, and reproduction in any medium, provided the original work is properly cited. 


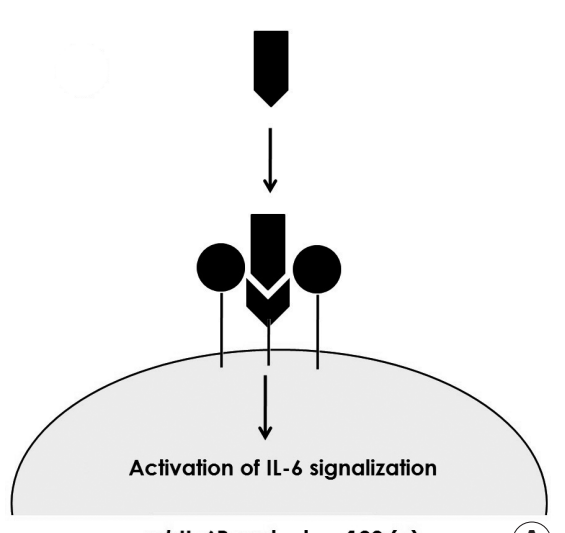

mblL-6R and mbgp $130(+)$

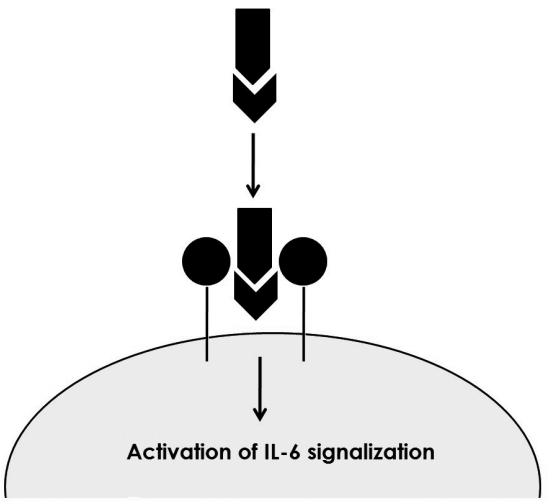

mbIL-6R (-) and mbgp130 (+)

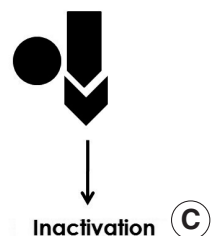

(B)
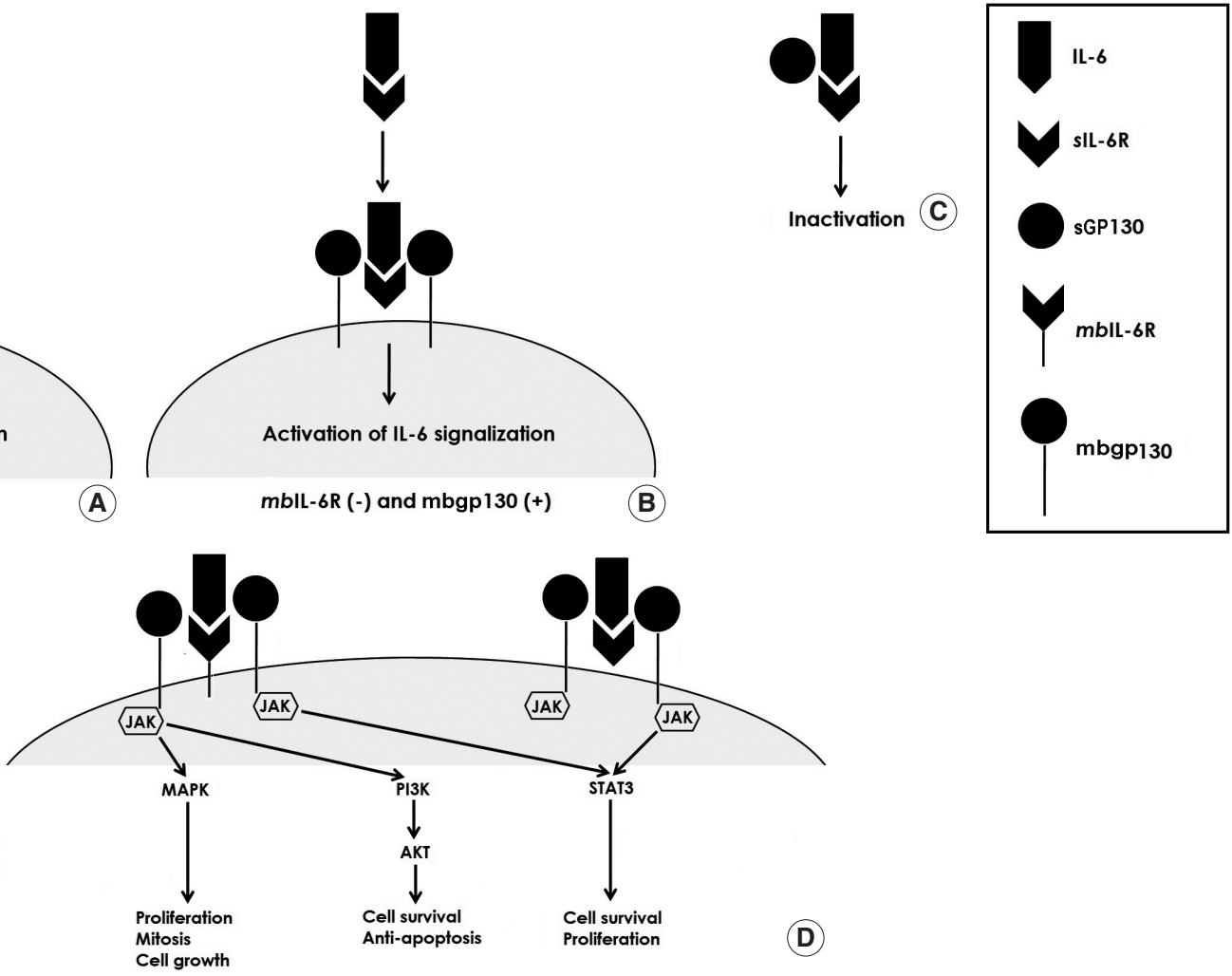

Fig. 1. (A-C) The activation of interleukin-6 (IL-6) signaling pathway. (D) IL-6 signaling pathways activated the Janus tyrosine kinase (JAK-STAT), PI3K signaling pathways and the Ras-MAPK mitogen activated protein kinase pathways which have several effects on inflammatory, autoimmune or malignant diseases.

thy that activation of the signaling pathway (canonical signaling pathway or trans-signaling pathway) occurs according to the interaction of IL-6 with different receptors. In addition, deactivation of these signaling pathways occurs when these receptors are blocked (Fig. 1A-C).

In the canonical signaling pathway (membrane bound IL-6R [mbIL-6R] (+) and membrane bound gp130 [mbgp130-common signal transducing component of IL-6 receptor] (+) cells), the dimerization of IL- 6 with membrane bound IL-6R and membrane bound gp130 results in a high affinity functional receptor complex called IL-6/IL-6R/gp130 (Fig. 1A). The Janus tyrosine kinase (JAK-STAT) and PI3K signaling pathways and the RasMAPK mitogen activated protein kinase pathways are activated

\section{H I}

- Interleukin-6 (IL-6) has several effects on inflammation and carcinogenesis and regulates the immune system.

- IL-6 is a candidate prognostic biomarker in patients with head and neck squamous cell carcinoma.

- IL-6 is correlated with aggressive and invasive tumor type.

- IL-6 targeted therapies are promising treatment modalities for patients with head and neck cancer. by this functional complex, and play an essential role in several inflammatory, autoimmune and malignant diseases. In mbIL-6R negative or low secreted cells, after complexing of IL-6 and sIL$6 \mathrm{R}$, this complex binds to mbgp130 and the signal pathway will be activated; this is called the "trans-signaling pathway" (Fig. 1B). Due to activation of this pathway, it is possible that the cells which are not responsive to IL- 6 under normal conditions are activated by sIL-6R. In fact, 70\% of the secreted IL-6 is complexed with sIL-6R and binds directly to mbgp130 protein while the other portion remains in serum temporarily and binds directly to $\mathrm{mbIL}$ 6R. Finally, the complex of sIL-6R/IL-6 in serum leads to inactivation of IL-6 as a consequence of sGP130 binding (Fig. 1C).

Currently, it is known that IL-6 plays a key role in several "hallmarks" (tumorigenesis, inducing angiogenesis, sustaining proliferative signaling, etc.) of solid cancers via triggering downstream activation of the JAK-STAT and PI3K signaling pathways (Fig. 1D). Thereby, dysregulation of IL-6 signaling promotes cancer cell proliferation and survival intrinsically and supports tumor growth via activating angiogenetic factors extrinsically. Hence, the purpose of this systematic review is to present a comprehensive and contemporary view of the association between IL-6 and different clinical and oncological aspects of HNSCC. 


\section{MATERIALS AND METHODS}

A systematic literature search was developed in accordance with the Preferred Reporting Items for Systematic Reviews and Meta-Analyses (PRISMA) guidelines and performed on PubMed/ Medline in the publication range from January 1995 to January 2019. The search terms were as follows: (interleukin 6) AND (head neck squamous cancer OR head neck squamous carcinoma OR oral cavity cancer OR oropharynx cancer OR oropharyngeal cancer OR larynx cancer OR laryngeal cancer OR tongue cancer OR hypopharynx cancer).

Clinical studies that evaluated the association between IL-6 and HNSCC and which were published in English were reviewed. Two blinded investigators (GE, UU) assessed the quality of each study using a standardized set of eight predefined criteria adapted from Slim et al. [18]. Studies were classified as high, moderate or low quality according to their scores. Any disagreements in the selection of studies were resolved by consensus.

\section{RESULTS}

In total, 99 studies met the inclusion criteria for the systematic review. Unfortunately, the authors were not able to perform a meta-analysis due to the marked heterogeneity in the definition of HNSCC, the lack of a consistent study design, and the small sample sizes.

\section{DISCUSSION}

\section{Serum IL-6 concentration and IL-6 expression in HNSCC}

Currently, it is known that IL-6 plays a crucial role in immunoregulation and tumorigenesis. Therefore, IL- 6 concentrations may increase in serum, saliva or at the tumor microenvironment of patients with HNSCC. Indeed, serum IL-6 concentrations were high in patients with HNSCC when compared with healthy controls [19]. On the other hand, Andersson et al. were unable to determine a statistically significant difference between plasma IL-6 concentrations in patients with HNSCC and healthy subjects [20]. In the literature, a variety of clinical studies have also reported higher serum IL-6 concentrations in patients with oral squamous cell carcinoma (OSCC) [21-23]. St John et al. [24] emphasized that serum IL-6 concentration might be used as a biomarker for OSCC (sensitivity, $57 \%$; specificity, $100 \%)$. They also demonstrated that its sensitivity and specificity rates increased up to $99 \%$ and $90 \%$, respectively, when serum IL- 6 and saliva IL-8 concentrations were used concurrently. In addition, serum IL- 6 concentrations were correlated with other inflammatory response biomarkers such as neutrophillymphocyte ratio and C-reactive protein levels in patients with OSCC [25]. Interestingly, Sotirovic et al. [26] were unable to demonstrate a significant difference between the serum IL-6 concentration of patients with laryngeal squamous cell carcinoma (LSCC) and control patients.

A clinical study, in which the relationships between health behaviors and pretreatment serum IL-6 concentrations of patients with HNSCC were evaluated, determined that current and former smoking status, poorer sleep scores, being older and higher tumor stage were significantly associated with higher serum IL-6 concentrations. However, alcohol intake, physical activity, body mass index, tumor location, race, education and income were not related to serum IL-6 concentrations in multivariate analysis [27]. On the other hand, Gao et al. [28] reported a correlation between history of alcohol consumption and IL-6 mRNA expression.

Human papilloma virus (HPV) 16 oncoproteins promote a proinflammatory cytokine "Oncostatin M" that promotes IL-6 expression; hence, viral oncoproteins induce IL-6 expression indirectly [29]. On the other hand, patients with HPV(+) had lower IL-6 concentrations than patients with HPV(-) [28]. The authors stated that $\mathrm{HPV}(+)$ cancer patients had better prognosis and the probable mechanism could be related to E6 and E7 oncoproteins that have significant effects on IL-6 regulation [28]. Moreover, Guerrera et al. [30] emphasized that IL-6 overexpression was particularly prominent at the HPV(-) tumor sites. Therefore, downregulation of IL-6 in HPV(+) patients with HNSCC might be associated with overexpressed cytokeratin proteins that may increase the sensitivity to radiochemotherapy.

\section{IL-6 is a prognostic biomarker in HNSCC}

Several studies have demonstrated the prognostic role of serum IL-6 concentrations and IL-6 overexpression in patients with HNSCC (Table 1). Serum IL-6 concentration was found to be an independent prognostic factor for overall- and disease free-survival in patients with OSCC [21]. In addition, longitudinal changes in serum IL- 6 concentrations may also be used for the prediction of survival in patients with locally advanced oropharyngeal squamous cell carcinoma [31]. Serum IL-6 concentration was inversely correlated with overall- and progression freesurvival in patients with LSCC [32]. Similarly, a significant association between high serum IL- 6 concentrations and a decrease in treatment response and survival was reported in patients with HNSCC treated with radiochemotherapy [33]. Furthermore, Duffy et al. [34] emphasized that pretreatment serum IL-6 concentration might be a good biomarker for the prediction of recurrence and overall survival in patients with HNSCC.

In the literature, the association between IL-6 overexpression and prognosis of patients with HNSCC has been demonstrated. Chen et al. [35] mentioned that IL-6 overexpression was associated with a significant decrease in survival of patients with pharyngeal squamous cell carcinoma. Similarly, several studies have reported that IL-6 expression was inversely related to prognosis and survival of patients with OSCC [28,36-38]. On the other 

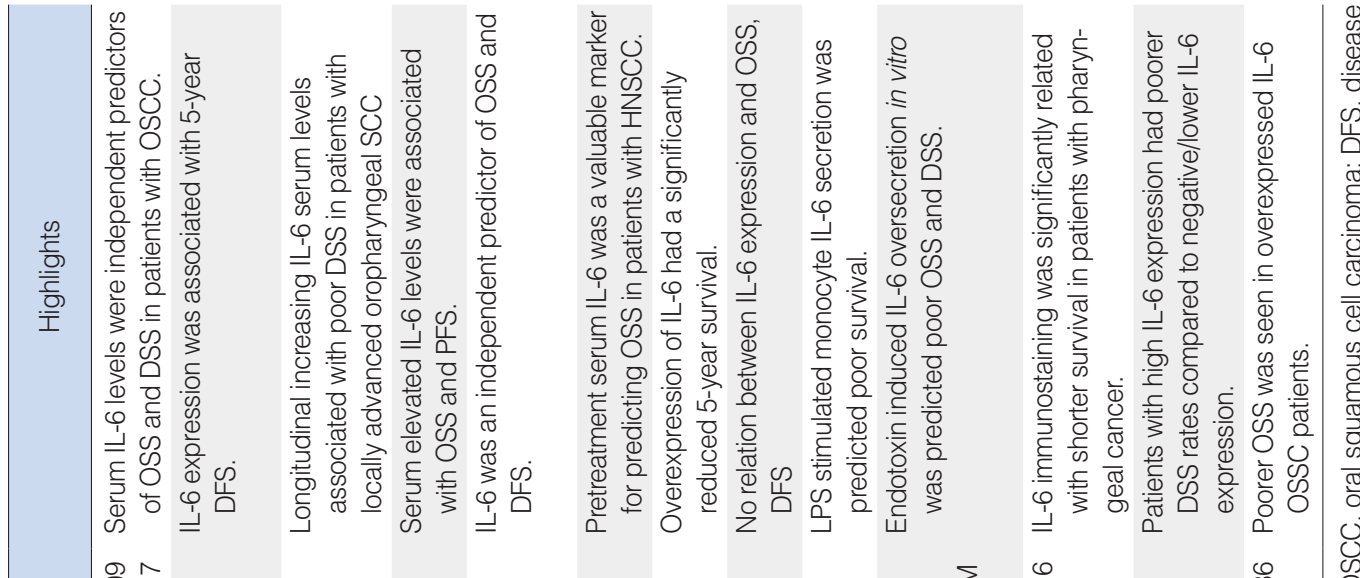

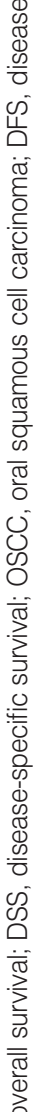

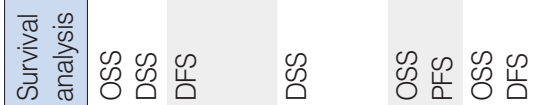

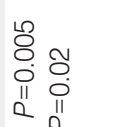

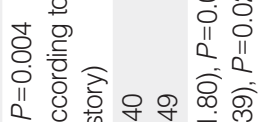

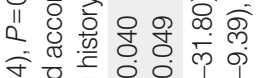

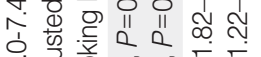
焉.

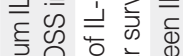

焉

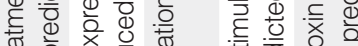

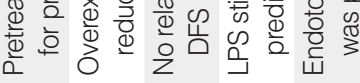

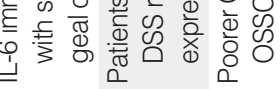

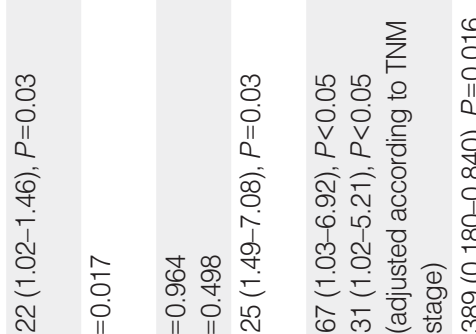

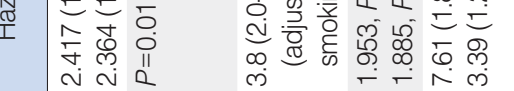

N II IIII

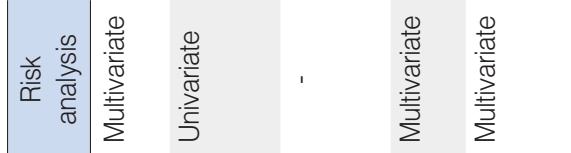

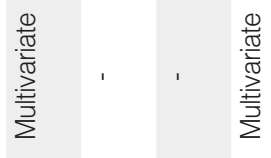

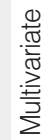

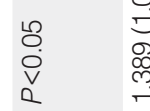

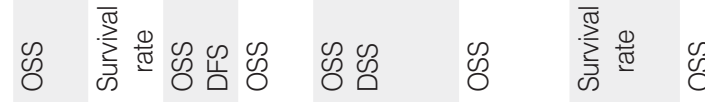

욱

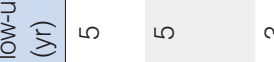

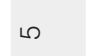

N

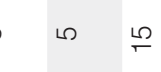

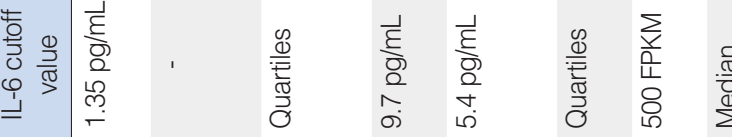

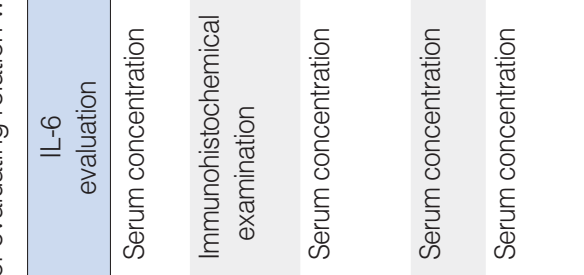

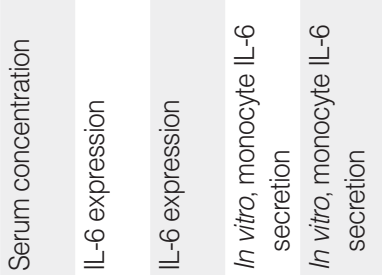

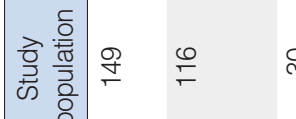

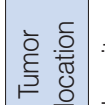

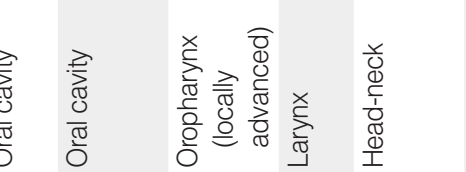

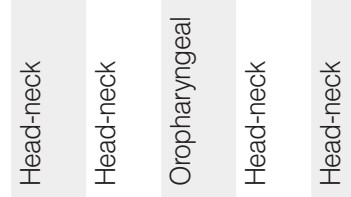

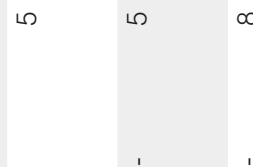

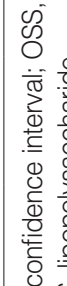

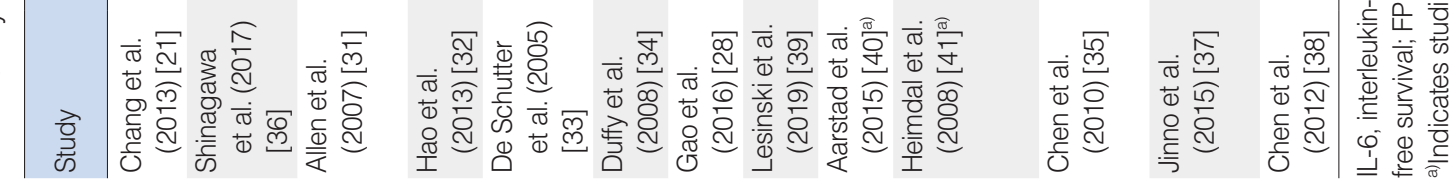


hand, IL-6 expression was not associated with overall survival in patients with oropharyngeal SCC [39].

In HNSCC, the production of IL-6 from peripheral blood monocytes after lipopolysaccharide (LPS) stimulation was higher than control group [42]. In comparison with control and HNSCC cells, LPS stimulated monocyte IL-6 overexpression in vivo predicted poor survival in patients with HNSCC [40]. Moreover, high LPS induced monocyte IL-6 endotoxin responsiveness was determined to be an adverse prognostic factor irrespective of TNM stage [41]. IL-6 secreted from endothelial cells induced the HNSCC cells motility towards blood vessels and survival [43].

IL-6 overexpression generally portends dismal prognosis when combined with other biomarkers. In patients with oropharyngeal cancers, IL- 6 and nuclear myoferlin (a member of the Ferlin family of proteins) overexpression had poorer survival rates (85\% mortality rate) when compared with tumors which only overexpressed nuclear myoferlin [44]. In addition, oropharyngeal cancers which overexpressed both protein arginine methlytransferase- 5 and IL- 6 had poorer survival rates compared to oropharyngeal cancers which only overexpressed protein arginine methlytransferase-5 [45].

\section{Salivary IL-6 concentrations in HNSCC}

Salivary IL-6 concentrations have been particularly evaluated in patients with oral and oropharyngeal diseases. Several studies have reported that the salivary IL-6 concentration in patients with OSCC was higher than in healthy subjects [46-52]. Similarly, the salivary IL-6 concentration was significantly higher in patients with OSCC when compared to patients with premalignant lesions [51,53]. A clinical study showed that salivary IL-6 concentrations were significantly higher in patients with OSCC when compared with healthy subjects and patients with chronic oral inflammatory diseases such as chronic periodontitis or oral lichen planus [54]; therefore, the role of salivary IL-6 for early detection of OSCC was clearly demonstrated. Furthermore, Korostoff et al. [55] emphasized that salivary IL-6 might be used for tongue cancer screening. IL-6R salivary angiogenic protein was found in excessive amount in saliva of HNSCC patients; hence, authors stated that it might be used as a potential diagnostic biomarker [56].

Salivary IL-6 is a candidate biomarker for the monitoring of treatment response in OSCC [47]. A significant decrease in salivary IL-6 concentration was detected after successful treatment of patients with OSCC. In addition, post-treatment salivary IL-6 concentration was an independent risk factor for locoregional recurrence in OSCC. Therefore, it might be used as a biomarker for the diagnosis of early and late locoregional recurrence [57,58]. Arduino et al. [59] stated that salivary IL-6 was more highly expressed in patients with OSCC than in a control group, and higher salivary IL- 6 concentrations were correlated with higher survival rates. In addition, Bossi et al. [60] compared the baseline and post-treatment salivary IL-6 concentrations in pa- tients with HNC and treated with radio and chemotherapy, and demonstrated that posttreatment IL-6 saliva levels might be used as a biomarker for the prediction of oral mucositis and inflammatory processes after radio and chemotherapy.

\section{Association between IL-6 and cancer cachexia in patients with HNSCC}

Cancer cachexia, a complex pathophysiological process, is principally characterized by an impaired anabolism and increased catabolism which leads to muscle wasting and progressive functional impairment, and a decrease in quality of life in patients with HNSCC [61,62]. It is currently known that cancer cachexia is triggered by several inflammatory mediators and neuroendocrine responses [61-63]. Recently, the association between IL-6 and cachexia has been clearly demonstrated [63-65]. In experimental models, elevated IL- 6 concentrations have been correlated with muscular atrophy, weight loss and hypophagia $[66,67]$. In an experimental oral cancer model, a specific angiotensin II receptor blocker (Telmisartan; Micardis, Boehringer Ingelheim, Ingelheim am Rhein, Germany), which also inhibits IL-6 expression, controlled cancer cachexia successfully when used in combination with cisplatin [68]. Similarly, Richey et al. [69] examined the association between several inflammatory mediators and cancer cachexia in patients with HNSCC and determined elevated serum IL-6 concentrations in patients with cachexia. However, a clinical study, which focused on the body composition of patients with HNSCC before and after radiochemotherapy, was unable to demonstrate a significant change in serum IL-6 concentration despite the development of cancer cachexia [70]. It is noteworthy that dietary pattern is likely to play a key role in serum IL-6 concentrations, and dietary supplementation with lycopene and carotenoid might reduce serum IL- 6 concentrations in patients with HNSCC [71].

\section{IL-6 gene polymorphism in different diseases of head and neck} IL-6 expression was found to be significantly higher in premalignant and malignant oral pathologies compared to healthy subjects [72]. Of note, IL-6 (-174) gene polymorphism was associated with oral premalignant lesions [73]. Moreover, IL-6 functional gene polymorphism (IL-6-174 G>C) had significant effects on the developmental risk of tobacco-related OSCC [74]. Although IL-6-174 G>C polymorphism was correlated with better survival in laryngopharyngeal cancers, IL-6-174 C/C had worse survival in oral cavity and hypopharyngeal cancer and better survival in LSCC [75]. A significant relationship between IL-6-174 gene polymorphism and OSCC was also reported [76]. Inflammation with IL-6 induction promoted tumorigenesis by altering global long interspersed nuclear element- 1 hypomethylation in the oral cavity [77].

Serum IL-6 concentrations were higher in patients with OSCC than in healthy subjects and patients with premalignant lesions [21]. On the other hand, no statistically significant differ- 
ence between patients with premalignant lesions and healthy individuals was determined. A study that evaluated the association of serum IL-6 concentrations in patients with leukoplakia and OSCC reported that IL-6 was not a good biomarker for the differential diagnosis of leukoplakia and OSCC. In addition, IL-6 expression was not different between oral premalignant and malignant lesions [72]. In contrast, Rhodus et al. reported that IL-6 concentrations increased significantly as the malignancy level increased when patients with OSCC, premalignant lesions (particularly lichen planus), and healthy cases compared [78]. Hence, the abovementioned data obviously indicate that higher salivary IL-6 concentrations are especially associated with malignant transformation of premalignant oral lesions.

\section{IL-6 and tumor characteristics in HNSCC}

IL-6 has a proliferative effect on the tumor microenvironment, and is likely to be associated with cancer progression, angiogenesis and metastases. Activation of the IL-6 signaling pathway induces aggressive cancer cell behavior such as higher tumor growth and invasion rate [35]. IL-6 overexpression was associated with the pattern of invasion, vascular invasion and pathological nodal status [36]. Therefore, IL-6 targeted therapies seem to be promising for the cessation of tumor growth and reducing tumor volume. Anti-IL-6 therapy might provide a decrease in endothelial cells, tubule formation and neoangiogenesis by blocking the autocrine growth mechanism [79]. IL-6 may induce antiapoptotic factors by activation of signal transducer and activator of transcription 3 (STAT3) and suppress cisplatin-induced apoptosis. In fact, IL-6 overexpression may indicate a low rate of treatment response in patients with OSCC treated with radiochemotherapy [37]. OSCC are not the only cells able to produce IL-6. Fibroblastic cells are also able to express IL-6 which might be one of the major mechanisms of bone destruction in patients with OSCC [80]. In addition, IL-6 and hepatocyte growth factor had a synergistic effect on tumor migration and invasion in HPV-negative oropharyngeal cancer cell lines [81].

Serum IL-6 also plays an important role in the progression of HNSCC. Elevated IL-6 levels were associated with tumor size and nodal metastasis in patients with OSCC [82]. In other study, elevated levels of IL-6 were related with higher T-stage, pathological stage, bone invasion and tumor depths in patients with OSCC [21]. Serum IL-6 concentrations were high in patients with T3/T4-stage, positive nodal metastases and advanced stage HNSCC $[19,83,84]$. Moreover, serum IL-6 concentrations were correlated with tumor stage and were higher in patients with stage IV HNSCC when compared with patients with stage I-III HNSCC [85]. They were positively correlated with tumor pathological stage such as grade, depth, activity, and invasiveness [86]. They were also correlated with local control and were an important indicator of radiotherapy responses in patients with $\mathrm{HN}$ SCC [33]. A clinical study in which 399 patients with HNSCC were evaluated showed that IL-6 overexpression indicated cisplatin resistance and was associated with poor prognosis [28]. Furthermore serum IL- 6 might be a potential predictive biomarker for resistance to dasatinib-cetuximab in patients with HNSCC [87]. In addition, blocking ERK dependent IL-6 signaling pathway enhanced the sensitivity to Buparlisib (PI3K inhibitor) in HNSCC patients [88]. Serum IL-6 was shown to be an independent risk factor for recurrence in OSCC [89]. Moreover, circulating IL-6 was a potent predictor of second primary cancer in patients with HNSCC [90].

\section{IL-6: a promising target for the treatment of HNSCC}

Novel therapeutic agents, which are specifically targeted to inhibit IL-6 mediated inflammation, are promising candidates for the treatment of HNSCC (Table 2) [91-126]. Moreover, endothelium secreted IL-6 and IL-6R promote self-renewal and survival of cancer stem-like cells. Therefore, inhibition of the IL-6

Table 2. IL-6 targeted agents for the treatment of HNSCC

\begin{tabular}{|c|c|c|c|}
\hline Study & Study design & Therapeutic agent & Highlights \\
\hline Chakravarti et al. (2006) [91] & In vitro & Curcumin & $\begin{array}{l}\text { Suppress IL-6 induced STAT3 } \\
\text { phosphorylation }\end{array}$ \\
\hline Cohen et al. (2009) [92] & In vitro & Curcumin & Suppress IL-6 production \\
\hline Meyer et al. (2011) [93] & In vitro & Curcumin & Suppress IL-6 secretion \\
\hline Yu et al. (2013) [94] & In vitro, in vivo & Curcumin & $\begin{array}{l}\text { Downregulate IL-6 expression and inhibition } \\
\text { of IL-6 signaling pathway }\end{array}$ \\
\hline Lin et al. (2012) [95] & In vitro & Epigallocatechin gallate & $\begin{array}{l}\text { Inhibit IL-6 induced JAK/STAT3 signaling } \\
\text { pathway }\end{array}$ \\
\hline Macha et al. (2011) [96] & In vitro & Guggulsterone & Block IL-6 signaling pathway \\
\hline Tamatani et al. (2007) [97] & In vitro & Cepharanthin & Suppress radiation induced IL-6 production \\
\hline Tu et al. (2016) [98] & In vitro & Luteolin & Block IL-6 signaling pathway \\
\hline Wolf et al. (2007) [99] & In vitro, in vivo & Human lactoferrin & Decrease IL-6 production \\
\hline Wichmann et al. (2017) [100] & Ex vivo & Cilengitide+cetuximab & Reduce IL-6 production \\
\hline Cui et al. (2005) [101] & In vivo & YM529 (third-generation bisphosphonate) & $\begin{array}{l}\text { Inhibit IL-6 effects and suppress bone } \\
\text { invasion }\end{array}$ \\
\hline
\end{tabular}


Table 2. Continued

\begin{tabular}{|c|c|c|c|}
\hline Study & Study design & Therapeutic agent & Highlights \\
\hline DiNatale et al. $(2011,2012)[102,103]$ & In vitro, in vitro & Aryl hydrocarbon receptor antagonist & Inhibit IL-6 expression \\
\hline Ekshyyan et al. (2016) [104] & In vitro & Rapamycin & Inhibit IL-6 expression \\
\hline Finkel et al. (2016) [105] & In vivo & MEDI5117 (humanized anti-IL-6 antibody) & $\begin{array}{l}\text { Inhibit IL-6 and inhibit recurrence in } \\
\text { preclinical models }\end{array}$ \\
\hline Hwang et al. (2016) [106] & In vitro, in vivo & $\begin{array}{l}\text { Targeting to insulin-like growth factor-II } \\
\text { mRNA binding protein-3 and podoplanin }\end{array}$ & $\begin{array}{l}\text { Inhibit IL-6 expression and suppress bone } \\
\text { invasion }\end{array}$ \\
\hline Islam et al. (2014) [107] & In vitro & Inhibition of RhoC & Reduce IL-6 expression \\
\hline Shinriki et al. $(2009,2011)[108,109]$ & $\begin{array}{l}\text { In vitro and in vivo, } \\
\text { in vitro and in vivo }\end{array}$ & Tocilizumab (anti-human IL-6R antibody) & Block angiogenesis and lymphangiogenesis \\
\hline Matsuoka et al. (2016) [110] & In vitro & Tocilizumab & $\begin{array}{l}\text { Sensitize radioresistant OSCC cells to } \\
\text { radiosensitive }\end{array}$ \\
\hline Stanam et al. (2015) [111] & In vivo & Tocilizumab & Overcome erlotinib resistance in HNSCC \\
\hline Poth et al. (2010) [112] & In vivo & Actemra (Tocilizumab) & Block IL-6 signaling \\
\hline Ruan et al. (2014) [113] & In vitro & Targeting to Toll-like receptor 9 protein & Block IL-6 stimulation \\
\hline Siavash et al. (2004) [114] & In vitro & Cyclopentenone prostaglandin 15d-PG $J_{2}$ & Inhibit IL-6 signaling pathway \\
\hline Tang et al. (2008) [115] & In vitro & $\begin{array}{l}\text { AMD3100 (chemokine receptor } 4 \text { inhibitor), } \\
\text { PD98059 (ERK inhibitor), PDTC (NF-kB } \\
\text { inhibitor) }\end{array}$ & $\begin{array}{l}\text { Inhibit IL-6 production and reduce } \\
\text { osteoclastogenesis }\end{array}$ \\
\hline Riebe et al. (2007) [116] & In vitro & SB203580 (p38 inhibitor) & Inhibit IL-6 secretion \\
\hline Jing et al. (2016) [117] & In vitro, in vivo & SB203580 & Reduce expression and secretion of IL-6 \\
\hline Kross et al. (2007) [118] & In vitro & L-leucine-methyl ester & Reduce IL-6 production \\
\hline Mishra et al. (2013) [119] & In vitro, in vivo & P276-00 (cyclin-dependent kinase inhibitor) & Suppress IL-6 production \\
\hline Sen et al. (2017) [120] & In vitro & Triazolothiadiazine and oxazole-piperazine & Inhibit IL-6 signaling pathway \\
\hline Teknos et al. (2005) [121] & In vitro, in vivo & Tetrathiomolybdate & $\begin{array}{l}\text { Decrease IL-6 levels, inhibit angiogenesis } \\
\text { and tumor growth }\end{array}$ \\
\hline $\begin{array}{l}\text { Van Tubergen et al. }(2011,2013) \\
{[122,123]}\end{array}$ & $\begin{array}{l}\text { In vitro, in vitro and } \\
\text { in vivo }\end{array}$ & Targeting to tristetraprolin & Regulate IL-6 secretion \\
\hline Zhou et al. (2014) [124] & In vitro, in vivo & WP1066 (STAT3 inhibitor) & $\begin{array}{l}\text { Block IL-6 signaling pathway and suppress } \\
\text { tumor growth }\end{array}$ \\
\hline Chang et al. (2018) [125] & In vitro & Honokiol & Reduce IL-6 secretion \\
\hline Wang et al. (2018) [126] & In vitro, in vivo & 2-O-Methylmagnolol & Inhibit IL-6/STAT3 signaling \\
\hline
\end{tabular}

IL-6, interleukin-6; HNSCC, head and neck squamous cell carcinoma; JAK-STAT, Janus tyrosine kinase; IL-6R, IL-6 receptor; OSCC, oral squamous cell carcinoma; ERK, extracellular signal-regulated kinase; PDTC, pyrrolidine dithiocarbamate; NF-kB, nuclear factor-kappa B.

signaling pathway may also reduce the fraction of cancer stemlike cells in HNSCC [127].

\section{CONCLUSION}

To the best of our knowledge, this is the first systematic review in which the role of IL- 6 and its signaling pathway in HNSCC has been comprehensively evaluated. It is clear that IL-6 plays several key roles in different aspects of HNSCC such as carcinogenesis, progression, invasiveness, angiogenesis and metastasis. The IL- 6 signaling pathway may also be related to cancer cachexia and may predict treatment response. Moreover, serum IL-6 concentrations and IL-6 expression are candidate prognostic biomarkers. IL- 6 targeted therapies are promising and may be added to the armamentarium of HNSCC therapeutics in the near future. However, prospective, well-designed, and appropriately analyzed large-scale clinical studies are required.

\section{CONFLICT OF INTEREST}

No potential conflict of interest relevant to this article was reported.

\section{ORCID}

$\begin{array}{ll}\text { Uzdan Uz } & \text { https://orcid.org/0000-0001-8973-3590 } \\ \text { Görkem Eskiizmir } & \text { https://orcid.org/0000-0002-3125-8288 }\end{array}$

\section{AUTHOR CONTRIBUTIONS}

Conceptualization, Data curation, Formal analysis, Methodology, Project administration, Visualization, Writing-original draft, review, \& editing: all authors. 


\section{REFERENCES}

1. Lee JM,Turini M, Botteman MF, Stephens JM, Pashos CL. Economic burden of head and neck cancer: a literature review. Eur J Health Econ. 2004 Feb;5(1):70-80.

2. Jemal A, Bray F, Center MM, Ferlay J, Ward E, Forman D. Global cancer statistics. CA Cancer J Clin. 2011 Mar-Apr;61(2):69-90.

3. Vokes EE, Weichselbaum RR, Lippman SM, Hong WK. Head and neck cancer. N Engl J Med. 1993 Jan;328(3):184-94.

4. Gregoire V, Lefebvre JL, Licitra L, Felip E; EHNS-ESMO-ESTRO Guidelines Working Group. Squamous cell carcinoma of the head and neck: EHNS-ESMO-ESTRO Clinical Practice Guidelines for diagnosis, treatment and follow-up. Ann Oncol. 2010 May;21 Suppl 5:v184-6.

5. Bernstein JM, Bernstein CR, West CM, Homer JJ. Molecular and cellular processes underlying the hallmarks of head and neck cancer. Eur Arch Otorhinolaryngol. 2013 Sep;270(10):2585-93.

6. Bose P, Brockton NT, Dort JC. Head and neck cancer: from anatomy to biology. Int J Cancer. 2013 Nov;133(9):2013-23.

7. Lin HS, Siddiq F, Talwar HS, Chen W, Voichita C, Draghici S, et al. Serum prognostic biomarkers in head and neck cancer patients. Laryngoscope. 2014 Aug;124(8):1819-26.

8. Lampri ES, Chondrogiannis G, Ioachim E, Varouktsi A, Mitselou A, Galani A, et al. Biomarkers of head and neck cancer, tools or a gordian knot? Int J Clin Exp Med. 2015 Jul;8(7):10340-57.

9. Guerra EN, Acevedo AC, Leite AF, Gozal D, Chardin H, De Luca Canto G. Diagnostic capability of salivary biomarkers in the assessment of head and neck cancer: a systematic review and meta-analysis. Oral Oncol. 2015 Sep;51(9):805-18.

10. Juodzbalys G, Kasradze D, Cicciu M, Sudeikis A, Banys L, GalindoMoreno P, et al. Modern molecular biomarkers of head and neck cancer. Part I. Epigenetic diagnostics and prognostics: systematic review. Cancer Biomark. 2016;17(4):487-502.

11. Guerra EN, Rego DF, Elias ST, Coletta RD, Mezzomo LA, Gozal D, et al. Diagnostic accuracy of serum biomarkers for head and neck cancer: a systematic review and meta-analysis. Crit Rev Oncol Hematol. 2016 May;101:93-118.

12. van Ginkel JH, Slieker FJ, de Bree R, van Es RJ, Van Cann EM,Willems SM. Cell-free nucleic acids in body fluids as biomarkers for the prediction and early detection of recurrent head and neck cancer: a systematic review of the literature. Oral Oncol. 2017 Dec;75: 8-15.

13. Burger R. Impact of interleukin-6 in hematological malignancies. Transfus Med Hemother. 2013 Oct;40(5):336-43.

14. Pencik J,Wiebringhaus R, Susani M, Culig Z, Kenner L. IL-6/STAT3/ ARF: the guardians of senescence, cancer progression and metastasis in prostate cancer. Swiss MedWkly. 2015 Dec;145:w14215.

15. Tsui KH, Wang SW, Chung LC, Feng TH, Lee TY, Chang PL, et al. Mechanisms by which interleukin- 6 attenuates cell invasion and tumorigenesis in human bladder carcinoma cells. Biomed Res Int. 2013;2013:791212.

16. Knupfer H, Preiss R. Significance of interleukin-6 (IL-6) in breast cancer (review). Breast Cancer ResTreat. 2007 Apr;102(2):129-35.

17. Xu J,YeY, Zhang H, Szmitkowski M, Makinen MJ, Li P, et al. Diagnostic and prognostic value of serum interleukin-6 in colorectal cancer. Medicine (Baltimore). 2016 Jan;95(2):e2502.

18. Slim K, Nini E, Forestier D, Kwiatkowski F, Panis Y, Chipponi J. Methodological index for non-randomized studies (minors): development and validation of a new instrument. ANZ J Surg. 2003 Sep;73(9): 712-6.

19. Riedel F, Zaiss I, Herzog D, Gotte K, Naim R, Hormann K. Serum levels of interleukin-6 in patients with primary head and neck squamous cell carcinoma. Anticancer Res. 2005 Jul-Aug;25(4):2761-5.

20. Andersson BA, Lewin F, Lundgren J, Nilsson M, Rutqvist LE, Lof- gren S, et al. Plasma tumor necrosis factor- $\alpha$ and C-reactive protein as biomarker for survival in head and neck squamous cell carcinoma. J Cancer Res Clin Oncol. 2014 Mar;140(3):515-9.

21. Chang KP, Kao HK, Wu CC, Fang KH, Chang YL, Huang YC, et al. Pretreatment interleukin- 6 serum levels are associated with patient survival for oral cavity squamous cell carcinoma. Otolaryngol Head Neck Surg. 2013 May;148(5):786-91.

22. Ren JG, Man QW, Zhang W, Li C, Xiong XP, Zhu JY, et al. Elevated level of circulating platelet-derived microparticles in oral cancer. $\mathrm{J}$ Dent Res. 2016 Jan;95(1):87-93.

23. Lotfi A, Shahidi N, Bayazian G, AbdollahiFakhim S, Estakhri R, Esfahani A, et al. Serum level of interleukin-6 in patients with oral tongue squamous cell carcinoma. Iran J Otorhinolaryngol. 2015 May;27(80):207-11.

24. St John MA, LiY, Zhou X, Denny P, Ho CM, Montemagno C, et al. Interleukin 6 and interleukin 8 as potential biomarkers for oral cavity and oropharyngeal squamous cell carcinoma. Arch Otolaryngol Head Neck Surg. 2004 Aug;130(8):929-35.

25. Nakashima H, Matsuoka Y, Yoshida R, Nagata M, Hirosue A, Kawahara $\mathrm{K}$, et al. Pre-treatment neutrophil to lymphocyte ratio predicts the chemoradiotherapy outcome and survival in patients with oral squamous cell carcinoma: a retrospective study. BMC Cancer. 2016 Jan;16:41.

26. Sotirovic J, Peric A, Vojvodic D, Baletic N, Zaletel I, Stanojevic I, et al. Serum cytokine profile of laryngeal squamous cell carcinoma patients. J Laryngol Otol. 2017 May;131(5):455-61.

27. Duffy SA,Teknos T, Taylor JM, Fowler KE, Islam M, Wolf GT, et al. Health behaviors predict higher interleukin-6 levels among patients newly diagnosed with head and neck squamous cell carcinoma. Cancer Epidemiol Biomarkers Prev. 2013 Mar;22(3):374-81.

28. Gao J, Zhao S, Halstensen TS. Increased interleukin- 6 expression is associated with poor prognosis and acquired cisplatin resistance in head and neck squamous cell carcinoma. Oncol Rep. 2016 Jun; 35(6):3265-74.

29. Chuerduangphui J, Pientong C, Chaiyarit P, Patarapadungkit N, Chotiyano A, Kongyingyoes B, et al. Effect of human papillomavirus 16 oncoproteins on oncostatin $\mathrm{M}$ upregulation in oral squamous cell carcinoma. Med Oncol. 2016 Aug;33(8):83.

30. Guerrera IC, Quetier I, Fetouchi R, Moreau F, Vauloup-Fellous C, Lekbaby B, et al. Regulation of interleukin- 6 in head and neck squamous cell carcinoma is related to papillomavirus infection. J Proteome Res. 2014 Feb;13(2):1002-11.

31. Allen C, Duffy S, Teknos T, Islam M, Chen Z, Albert PS, et al. Nuclear factor-kappaB-related serum factors as longitudinal biomarkers of response and survival in advanced oropharyngeal carcinoma. Clin Cancer Res. 2007 Jun;13(11):3182-90.

32. Hao W, Zhu Y, Zhou H. Prognostic value of interleukin-6 and interleukin-8 in laryngeal squamous cell cancer. Med Oncol. 2013 Mar; 30(1):333.

33. De Schutter H, Landuyt W, Verbeken E, Goethals L, Hermans R, Nuyts S. The prognostic value of the hypoxia markers CA IX and GLUT 1 and the cytokines VEGF and IL 6 in head and neck squamous cell carcinoma treated by radiotherapy +/- chemotherapy. BMC Cancer. 2005 Apr;5:42.

34. Duffy SA, Taylor JM, Terrell JE, Islam M, Li Y, Fowler KE, et al. Interleukin-6 predicts recurrence and survival among head and neck cancer patients. Cancer. 2008 Aug;113(4):750-7.

35. Chen CC, Chen WC, Lu CH, Wang WH, Lin PY, Lee KD, et al. Significance of interleukin- 6 signaling in the resistance of pharyngeal cancer to irradiation and the epidermal growth factor receptor inhibitor. Int J Radiat Oncol Biol Phys. 2010 Mar;76(4):1214-24.

36. Shinagawa K, Yanamoto S, NaruseT, Kawakita A, Morishita K, SakamotoY, et al. Clinical roles of interleukin-6 and STAT3 in oral squamous cell carcinoma. Pathol Oncol Res. 2017 Apr;23(2):425-31. 
37. Jinno T, Kawano S, Maruse Y, Matsubara R, Goto Y, Sakamoto T, et al. Increased expression of interleukin- 6 predicts poor response to chemoradiotherapy and unfavorable prognosis in oral squamous cell carcinoma. Oncol Rep. 2015 May;33(5):2161-8.

38. Chen CJ, Sung WW, Lin YM, Chen MK, Lee CH, Lee H, et al. Gender difference in the prognostic role of interleukin 6 in oral squamous cell carcinoma. PLoS One. 2012;7(11):e50104.

39. Lesinski GB, Nannapaneni S, Griffith CC, Patel M, ChenW, Chen Z, et al. Interleukin-6/STAT3 signaling is prominent and associated with reduced overall survival in p16 negative oropharyngeal squamous cell carcinoma. Head Neck Pathol. 2019 Sep;13(3):304-12.

40. Aarstad HH, Vintermyr OK, Ulvestad E, Kross K, Heimdal JH, Aarstad HJ. In vitro-stimulated IL-6 monocyte secretion and in vivo peripheral blood $t$ lymphocyte activation uniquely predicted 15-year survival in patients with head and neck squamous cell carcinoma. PLoS One. 2015 Jun;10(6):e0129724.

41. Heimdal JH, Kross K, Klementsen B, Olofsson J, Aarstad HJ. Stimulated monocyte IL- 6 secretion predicts survival of patients with head and neck squamous cell carcinoma. BMC Cancer. 2008 Jan; 8:34.

42. Gallo O, Gori AM, Attanasio M, Martini F, Giusti B, Boddi M, et al. Interleukin-1 beta and interleukin- 6 release by peripheral blood monocytes in head and neck cancer. Br J Cancer. 1993 Sep;68(3): 465-8.

43. Kim HS, Chen YC, Nor F, Warner KA, Andrews A, WagnerVP, et al. Endothelial-derived interleukin- 6 induces cancer stem cell motility by generating a chemotactic gradient towards blood vessels. Oncotarget. 2017 Nov;8(59):100339-52.

44. Kumar B, Brown NV, Swanson BJ, SchmittAC, Old M, Ozer E, et al. High expression of myoferlin is associated with poor outcome in oropharyngeal squamous cell carcinoma patients and is inversely associated with HPV-status. Oncotarget. 2016 Apr;7(14):18665-77.

45. Kumar B, Yadav A, Brown NV, Zhao S, Cipolla MJ,Wakely PE, et al. Nuclear PRMT5, cyclin D1 and IL-6 are associated with poor outcome in oropharyngeal squamous cell carcinoma patients and is inversely associated with p16-status. Oncotarget. 2017 Feb;8(9): 14847-59.

46. SahebJamee M, Eslami M, AtarbashiMoghadam F, Sarafnejad A. Salivary concentration of TNFalpha, IL1 alpha, IL6, and IL8 in oral squamous cell carcinoma. Med Oral Patol Oral Cir Bucal. 2008 May; 13(5):E292-5.

47. Sato J, Goto J, Murata T, Kitamori S, Yamazaki Y, Satoh A, et al. Changes in saliva interleukin-6 levels in patients with oral squamous cell carcinoma. Oral Surg Oral Med Oral Pathol Oral Radiol Endod. 2010 Sep;110(3):330-6.

48. Vucicevic Boras V, Cikes N, Lukac J, Virag M, Cekic-Arambasin A. Salivary and serum interleukin 6 and basic fibroblast growth factor levels in patients with oral squamous cell carcinoma. Minerva Stomatol. 2005 Oct;54(10):569-73.

49. Katakura A, Kamiyama I, Takano N, Shibahara T, Muramatsu T, Ishihara $\mathrm{K}$, et al. Comparison of salivary cytokine levels in oral cancer patients and healthy subjects. Bull Tokyo Dent Coll. 2007 Nov;48(4):199-203.

50. Hamad AW, Gaphor SM, Shawagfeh MT,Al-Talabani NG. Study of serum and salivary levels of proinflammatory cytokines, potential biomarkers in the diagnosis of oral squamous cell carcinoma. Acad J Cancer. 2011;4(2):47-55.

51. Panneer Selvam N, Sadaksharam J. Salivary interleukin-6 in the detection of oral cancer and precancer. Asia Pac J Clin Oncol. 2015 Sep;11(3):236-41.

52. Zhang S, Zhang X, Yin K, Li T, BaoY, Chen Z.Variation and significance of secretory immunoglobulin A, interleukin 6 and dendritic cells in oral cancer. Oncol Lett. 2017 Apr;13(4):2297-303.

53. Juretic M, Cerovic R, Belusic-Gobic M, Brekalo Prso I, Kqiku L,
Spalj S, et al. Salivary levels of TNF- $\alpha$ and IL-6 in patients with oral premalignant and malignant lesions. Folia Biol (Praha). 2013;59(2): 99-102.

54. Lisa Cheng YS, Jordan L, Gorugantula LM, Schneiderman E, Chen HS, Rees T. Salivary interleukin-6 and -8 in patients with oral cancer and patients with chronic oral inflammatory diseases. J Periodontol. 2014 Jul;85(7):956-65.

55. Korostoff A, Reder L, Masood R, Sinha UK. The role of salivary cytokine biomarkers in tongue cancer invasion and mortality. Oral Oncol. 2011 Apr;47(4):282-7.

56. van der Merwe L, Wan Y, Cheong HJ, Perry C, Punyadeera C. A pilot study to profile salivary angiogenic factors to detect head and neck cancers. BMC Cancer. 2018 Jul;18(1):734.

57. Sato J, Ohuchi M, Abe K, Satoh T, Abe T, YamazakiY, et al. Correlation between salivary interleukin-6 levels and early locoregional recurrence in patients with oral squamous cell carcinoma: preliminary study. Head Neck. 2013 Jun;35(6):889-94.

58. Sato J, Ohuchi M, Wada M, Ohga N, Asaka T, Yoshikawa K, et al. Differences in sequential posttreatment salivary IL-6 levels between patients with and patients without locoregional recurrences of oral squamous cell carcinoma: part III of a cohort study. Oral Surg Oral Med Oral Pathol Oral Radiol. 2015 Dec;120(6):751-60.

59. Arduino PG, Menegatti E, Cappello N, Martina E, Gardino N, Tanteri $\mathrm{C}$, et al. Possible role for interleukins as biomarkers for mortality and recurrence in oral cancer. Int J Biol Markers. 2015 May; 30(2):e262-6.

60. Bossi P, Bergamini C, Miceli R, Cova A, Orlandi E, Resteghini C, et al. Salivary cytokine levels and oral mucositis in head and neck cancer patients treated with chemotherapy and radiation therapy. Int J Radiat Oncol Biol Phys. 2016 Dec;96(5):959-66.

61. Couch ME, Dittus K, Toth MJ,Willis MS, Guttridge DC, George JR, et al. Cancer cachexia update in head and neck cancer: definitions and diagnostic features. Head Neck. 2015 Apr;37(4):594-604.

62. Couch ME, Dittus K, Toth MJ,Willis MS, Guttridge DC, George JR, et al. Cancer cachexia update in head and neck cancer: pathophysiology and treatment. Head Neck. 2015 Jul;37(7):1057-72.

63. Fearon KC, Glass DJ, Guttridge DC. Cancer cachexia: mediators, signaling, and metabolic pathways. Cell Metab. 2012 Aug;16(2): 153-66.

64. Narsale AA, Carson JA. Role of interleukin-6 in cachexia: therapeutic implications. Curr Opin Support Palliat Care. 2014 Dec;8(4): 321-7.

65. Onesti JK, Guttridge DC. Inflammation based regulation of cancer cachexia. Biomed Res Int. 2014;2014:168407.

66. TsujinakaT, Fujita J, Ebisui C, Yano M, Kominami E, Suzuki K, et al. Interleukin 6 receptor antibody inhibits muscle atrophy and modulates proteolytic systems in interleukin 6 transgenic mice. J Clin Invest. 1996 Jan;97(1):244-9.

67. Black K, Garrett IR, Mundy GR. Chinese hamster ovarian cells transfected with the murine interleukin-6 gene cause hypercalcemia as well as cachexia, leukocytosis and thrombocytosis in tumor-bearing nude mice. Endocrinology. 1991 May;128(5):2657-9.

68. Patel BM, Damle D. Combination of telmisartan with cisplatin controls oral cancer cachexia in rats. Biomed Res Int. 2013;2013:642848.

69. Richey LM, George JR, Couch ME, Kanapkey BK, Yin X, Cannon T, et al. Defining cancer cachexia in head and neck squamous cell carcinoma. Clin Cancer Res. 2007 Nov;13(22 Pt 1):6561-7.

70. de Carvalho TM, Miguel Marin D, da Silva CA, de Souza AL, Talamoni M, Lima CS, et al. Evaluation of patients with head and neck cancer performing standard treatment in relation to body composition, resting metabolic rate, and inflammatory cytokines. Head Neck. 2015 Jan;37(1):97-102.

71. Arthur AE, Peterson KE, Shen J, Djuric Z, Taylor JM, Hebert JR, et al. Diet and proinflammatory cytokine levels in head and neck 
squamous cell carcinoma. Cancer. 2014 Sep;120(17):2704-12.

72. Kamperos G, Nikitakis N, Sfakianou A, Avgoustidis D, SklavounouAndrikopoulou A. Expression of NF- $\mathrm{kB}$ and IL-6 in oral precancerous and cancerous lesions: an immunohistochemical study. Med Oral Patol Oral Cir Bucal. 2016 Jan;21(1):e6-13.

73. Hsu HJ, Yang YH, Shieh TY, Chen CH, Kao YH, Yang CF, et al. Role of cytokine gene (interferon- $\gamma$, transforming growth factor- $\beta 1$, tumor necrosis factor- $\alpha$, interleukin- 6 , and interleukin-10) polymorphisms in the risk of oral precancerous lesions in Taiwanese. Kaohsiung J Med Sci. 2014 Nov;30(11):551-8.

74. Gaur P, Mittal M, Mohanti B, Das S. Functional variants of IL4 and IL6 genes and risk of tobacco-related oral carcinoma in high-risk Asian Indians. Oral Dis. 2011 Oct;17(7):720-6.

75. Lopez RV, Zago MA, Eluf-Neto J, Curado MP, Daudt AW, da SilvaJuniorWA, et al. Education, tobacco smoking, alcohol consumption, and IL-2 and IL-6 gene polymorphisms in the survival of head and neck cancer. Braz J Med Biol Res. 2011 Oct;44(10):1006-12.

76. Singh PK, Chandra G, Bogra J, Gupta R, KumarV, Jain A, et al. Association of interleukin-6 genetic polymorphisms with risk of OSCC in Indian population. Meta Gene. 2015 May;4:142-51.

77. Gasche JA, Hoffmann J, Boland CR, Goel A. Interleukin-6 promotes tumorigenesis by altering DNA methylation in oral cancer cells. Int J Cancer. 2011 Sep;129(5):1053-63.

78. Rhodus NL, Cheng B, Myers S, Miller L, Ho V, Ondrey F. The feasibility of monitoring NF-kappaB associated cytokines: TNF-alpha, IL-1alpha, IL-6, and IL-8 in whole saliva for the malignant transformation of oral lichen planus. Mol Carcinog. 2005 Oct;44(2):77-82.

79. Bran G, Gotte K, Riedel K, Hormann K, Riedel F. IL-6 antisensemediated growth inhibition in a head and neck squamous cell carcinoma cell line. In Vivo. 2011 Jul-Aug;25(4):579-84.

80. Kayamori K, Sakamoto K, Nakashima T, Takayanagi H, Morita K, Omura K, et al. Roles of interleukin- 6 and parathyroid hormonerelated peptide in osteoclast formation associated with oral cancers: significance of interleukin- 6 synthesized by stromal cells in response to cancer cells. Am J Pathol. 2010 Feb;176(2):968-80.

81. Bolt R, Foran B, Murdoch C, Lambert DW, Thomas S, Hunter KD. HPV-negative, but not HPV-positive, oropharyngeal carcinomas induce fibroblasts to support tumour invasion through micro-environmental release of HGF and IL-6. Carcinogenesis. 2018 Feb;39(2): 170-9.

82. Schiegnitz E, Kammerer PW, Schon H, Blatt S, Berres M, Sagheb K, et al. Proinflammatory cytokines as serum biomarker in oral carcinoma-A prospective multi-biomarker approach. J Oral Pathol Med. 2018 Mar;47(3):268-74.

83. Sparano A, Lathers DM, Achille N, Petruzzelli GJ, Young MR. Modulation of Th1 and Th2 cytokine profiles and their association with advanced head and neck squamous cell carcinoma. Otolaryngol Head Neck Surg. 2004 Nov;131(5):573-6.

84. Li C, Zhao Y, Zhang W, Zhang W. Increased prevalence of T(H)17 cells in the peripheral blood of patients with head and neck squamous cell carcinoma. Oral Surg Oral Med Oral Pathol Oral Radiol Endod. 2011 Jul;112(1):81-9.

85. Mojtahedi Z, Khademi B, Hashemi SB, Abtahi SM, Ghasemi MA, Fattahi MJ, et al. Serum interleukine- 6 concentration, but not interleukine-18, is associated with head and neck squamous cell carcinoma progression. Pathol Oncol Res. 2011 Mar;17(1):7-10.

86. Chang PY, Kuo YB, Wu TL, Liao CT, Sun YC, Yen TC, et al. Association and prognostic value of serum inflammation markers in patients with leukoplakia and oral cavity cancer. Clin Chem Lab Med. 2013 Jun;51(6):1291-300.

87. Stabile LP, Egloff AM, Gibson MK, Gooding WE, Ohr J, Zhou P, et al. IL6 is associated with response to dasatinib and cetuximab: phase II clinical trial with mechanistic correlatives in cetuximab-resistant head and neck cancer. Oral Oncol. 2017 Jun;69:38-45.
88. Yun MR, Choi HM, Kang HN, Lee Y, Joo HS, Kim DH, et al. ERKdependent IL- 6 autocrine signaling mediates adaptive resistance to pan-PI3K inhibitor BKM120 in head and neck squamous cell carcinoma. Oncogene. 2018 Jan;37(3):377-88.

89. Skrinjar I, Brailo V, Vidovic-Juras D, Vucicevic-Boras V, Milenovic A. Evaluation of pretreatment serum interleukin- 6 and tumour necrosis factor alpha as a potential biomarker for recurrence in patients with oral squamous cell carcinoma. Med Oral Patol Oral Cir Bucal. $2015 \mathrm{Jul} ; 20(4): \mathrm{e} 402-7$.

90. Cottin SC, Turcotte S, Douville P, Meyer F, Bairati I. Predictors of circulating INTERLEUKIN-6 levels in head and neck cancer patients. Cancers Head Neck. 2018;3:1.

91. Chakravarti N, Myers JN, Aggarwal BB. Targeting constitutive and interleukin-6-inducible signal transducers and activators of transcription 3 pathway in head and neck squamous cell carcinoma cells by curcumin (diferuloylmethane). Int J Cancer. 2006 Sep; 119(6):1268-75.

92. Cohen AN, Veena MS, Srivatsan ES, Wang MB. Suppression of interleukin 6 and 8 production in head and neck cancer cells with curcumin via inhibition of Ikappa beta kinase. Arch Otolaryngol Head Neck Surg. 2009 Feb;135(2):190-7.

93. Meyer C, Pries R, Wollenberg B. Established and novel NF-кB inhibitors lead to downregulation of TLR3 and the proliferation and cytokine secretion in HNSCC. Oral Oncol. 2011 Sep;47(9):818-26.

94. Yu CC,Tsai LL, Wang ML, Yu CH, Lo WL, Chang YC, et al. miR145 targets the SOX9/ADAM17 axis to inhibit tumor-initiating cells and IL-6-mediated paracrine effects in head and neck cancer. Cancer Res. 2013 Jun;73(11):3425-40.

95. Lin HY, Hou SC, Chen SC, Kao MC, Yu CC, Funayama S, et al. (-)-Epigallocatechin gallate induces Fas/CD95-mediated apoptosis through inhibiting constitutive and IL-6-induced JAK/STAT3 signaling in head and neck squamous cell carcinoma cells. J Agric Food Chem. 2012 Mar;60(10):2480-9.

96. Macha MA, Matta A, Chauhan SS, Siu KW, Ralhan R. Guggulsterone (GS) inhibits smokeless tobacco and nicotine-induced NF-kB and STAT3 pathways in head and neck cancer cells. Carcinogenesis. 2011 Mar;32(3):368-80.

97. TamataniT,Azuma M, Motegi K,Takamaru N, KawashimaY, Bando T. Cepharanthin-enhanced radiosensitivity through the inhibition of radiation-induced nuclear factor-kappaB activity in human oral squamous cell carcinoma cells. Int J Oncol. 2007 Oct;31(4):761-8.

98. Tu DG, Lin WT, Yu CC, Lee SS, Peng CY, Lin T, et al. Chemotherapeutic effects of luteolin on radio-sensitivity enhancement and interleukin-6/signal transducer and activator of transcription 3 signaling repression of oral cancer stem cells. J Formos Med Assoc. 2016 Dec;115(12):1032-8.

99. Wolf JS, Li G, Varadhachary A, Petrak K, Schneyer M, Li D, et al. Oral lactoferrin results in T cell-dependent tumor inhibition of head and neck squamous cell carcinoma in vivo. Clin Cancer Res. 2007 Mar;13(5):1601-10.

100. Wichmann G, Cedra S, Schlegel D, Kolb M, Wiegand S, Boehm A, et al. Cilengitide and cetuximab reduce cytokine production and colony formation of head and neck squamous cell carcinoma cells ex vivo. Anticancer Res. 2017 Feb;37(2):521-7.

101. Cui N, Nomura T, Noma H, Yokoo K, Takagi R, Hashimoto S, et al. Effect of YM529 on a model of mandibular invasion by oral squamous cell carcinoma in mice. Clin Cancer Res. 2005 Apr;11(7): 2713-9.

102. DiNatale BC, Schroeder JC, Perdew GH. Ah receptor antagonism inhibits constitutive and cytokine inducible IL6 production in head and neck tumor cell lines. Mol Carcinog. 2011 Mar;50(3):173-83.

103. DiNatale BC, Smith K, John K, Krishnegowda G,Amin SG, Perdew $\mathrm{GH}$. Ah receptor antagonism represses head and neck tumor cell aggressive phenotype. Mol Cancer Res. 2012 Oct;10(10):1369-79. 
104. Ekshyyan O, Khandelwal AR, Rong X, Moore-Medlin T, Ma X, Alexander JS, et al. Rapamycin targets Interleukin 6 (IL-6) expression and suppresses endothelial cell invasion stimulated by tumor cells. Am JTransl Res. 2016 Nov;8(11):4822-30.

105. Finkel KA, Warner KA, Kerk S, Bradford CR, McLean SA, Prince ME, et al. IL-6 Inhibition with MEDI5117 decreases the fraction of head and neck cancer stem cells and prevents tumor recurrence. Neoplasia. 2016 May;18(5):273-81.

106. Hwang YS, Ahn SY, Moon S, Zheng Z, Cha IH, Kim J, et al. Insulinlike growth factor-II mRNA binding protein-3 and podoplanin expression are associated with bone invasion and prognosis in oral squamous cell carcinoma. Arch Oral Biol. 2016 Sep;69:25-32.

107. Islam M, Sharma S, Teknos TN. RhoC regulates cancer stem cells in head and neck squamous cell carcinoma by overexpressing IL-6 and phosphorylation of STAT3. PLoS One. 2014 Feb;9(2):e88527.

108. Shinriki S, Jono H, Ota K, Ueda M, Kudo M, Ota T, et al. Humanized anti-interleukin-6 receptor antibody suppresses tumor angiogenesis and in vivo growth of human oral squamous cell carcinoma. Clin Cancer Res. 2009 Sep;15(17):5426-34.

109. Shinriki S, Jono H, Ueda M, Ota K, Ota T, Sueyoshi T, et al. Interleukin-6 signalling regulates vascular endothelial growth factor-C synthesis and lymphangiogenesis in human oral squamous cell carcinoma. J Pathol. 2011 Sep;225(1):142-50.

110. Matsuoka Y, Nakayama H, Yoshida R, Hirosue A, Nagata M,Tanaka T, et al. IL-6 controls resistance to radiation by suppressing oxidative stress via the Nrf2-antioxidant pathway in oral squamous cell carcinoma. Br J Cancer. 2016 Nov;115(10):1234-44.

111. Stanam A, Love-Homan L, Joseph TS, Espinosa-Cotton M, Simons AL. Upregulated interleukin-6 expression contributes to erlotinib resistance in head and neck squamous cell carcinoma. Mol Oncol. 2015 Aug;9(7):1371-83.

112. Poth KJ, Guminski AD, Thomas GP, Leo PJ, Jabbar IA, Saunders NA. Cisplatin treatment induces a transient increase in tumorigenic potential associated with high interleukin- 6 expression in head and neck squamous cell carcinoma. Mol Cancer Ther. 2010 Aug;9(8): 2430-9.

113. Ruan M, Thorn K, Liu S, Li S, Yang W, Zhang C, et al. The secretion of IL-6 by CpG-ODN-treated cancer cells promotes T-cell immune responses partly through the TLR-9/AP-1 pathway in oral squamous cell carcinoma. Int J Oncol. 2014 Jun;44(6):2103-10.

114. Siavash H, Nikitakis NG, Sauk JJ. Abrogation of IL-6-mediated JAK signaling by the cyclopentenone prostaglandin 15d-PGJ(2) in oral squamous carcinoma cells. Br J Cancer. 2004 Sep;91(6):1074-80.

115. Tang CH, Chuang JY, Fong YC, Maa MC, Way TD, Hung CH. Bonederived SDF-1 stimulates IL-6 release via CXCR4, ERK and NFkappaB pathways and promotes osteoclastogenesis in human oral cancer cells. Carcinogenesis. 2008 Aug;29(8):1483-92.
116. Riebe C, Pries R, Kemkers A, Wollenberg B. Increased cytokine secretion in head and neck cancer upon p38 mitogen-activated protein kinase activation. Int J Mol Med. 2007 Dec;20(6):883-7.

117. Jing Z, Xu H, Chen X, Zhong Q, Huang J, Zhang Y, et al. The proton-sensing G-protein coupled receptor GPR4 promotes angiogenesis in head and neck cancer. PLoS One. 2016 Apr;11(4):e0152789.

118. Kross KW, Heimdal JH, Olsnes C, Olofson J, Aarstad HJ. Tumourassociated macrophages secrete IL-6 and MCP-1 in head and neck squamous cell carcinoma tissue. Acta Otolaryngol. 2007 May; 127(5):532-9.

119. Mishra PB, Lobo AS, Joshi KS, Rathos MJ, Kumar GA, Padigaru M. Molecular mechanisms of anti-tumor properties of P276-00 in head and neck squamous cell carcinoma. J Transl Med. 2013 Feb; 11:42.

120. Sen M, Johnston PA, Pollock NI, DeGrave K, Joyce SC, Freilino ML, et al. Mechanism of action of selective inhibitors of IL-6 induced STAT3 pathway in head and neck cancer cell lines. J Chem Biol. 2017 May;10(3):129-41.

121. TeknosTN, Islam M,Arenberg DA, Pan Q, Carskadon SL,Abarbanell $\mathrm{AM}$, et al.The effect of tetrathiomolybdate on cytokine expression, angiogenesis, and tumor growth in squamous cell carcinoma of the head and neck. Arch Otolaryngol Head Neck Surg. 2005 Mar; 131(3):204-11.

122. Van Tubergen E,Vander Broek R, Lee J,Wolf G, CareyT, Bradford C, et al.Tristetraprolin regulates interleukin-6, which is correlated with tumor progression in patients with head and neck squamous cell carcinoma. Cancer. 2011 Jun;117(12):2677-89.

123. Van Tubergen EA, Banerjee R, Liu M,Vander Broek R, Light E, Kuo $\mathrm{S}$, et al. Inactivation or loss of TTP promotes invasion in head and neck cancer via transcript stabilization and secretion of MMP9, MMP2, and IL-6. Clin Cancer Res. 2013 Mar;19(5):1169-79.

124. Zhou X, Ren Y, Liu A, Han L, Zhang K, Li S, et al. STAT3 inhibitor WP1066 attenuates miRNA-21 to suppress human oral squamous cell carcinoma growth in vitro and in vivo. Oncol Rep. 2014 May; 31(5):2173-80.

125. Chang MT, Lee SP, Fang CY, Hsieh PL, Liao YW, Lu MY, et al. Chemosensitizing effect of honokiol in oral carcinoma stem cells via regulation of IL-6/Stat3 signaling. EnvironToxicol. 2018 Nov;33(11): 1105-12.

126. Wang TH, Fang JY, Wu SJ, Liu YW, Chan CW, Chuang SY, et al. 2-O-methylmagnolol induces apoptosis and inhibits IL-6/STAT3 signaling in oral squamous cell carcinoma. Cell Physiol Biochem. 2018;50(3):883-92.

127. Krishnamurthy S, Warner KA, Dong Z, Imai A, Nor C, Ward BB, et al. Endothelial interleukin- 6 defines the tumorigenic potential of primary human cancer stem cells. Stem Cells. 2014 Nov;32(11): 2845-57. 